\title{
EFEKTIVITAS PELATIHAN MODAL PSIKOLOGIS TERHADAP KETERIKATAN KERJA PEGAWAI RESTO KOPI X SALATIGA
}

\section{Adi Wijaya}

Universitas Kristen Satya Wacana Salatiga Jawa Tengah, Indonesia

Email: adi.wijaya@uksw.edu

\begin{tabular}{ll}
\hline INFO ARTIKEL & ABSTRACK \\
\hline Diterima & Enhancing the quality of the employees in COVID-19 \\
24 Januari 2021 & pandemic era is an important thing to do. The main \\
Direvisi & reason is because that superior employees is a primary \\
12 Februari 2021 & needs for the entrepreneur to have in the post-pandemic \\
Disetujui & era. This field experimental research in the form of \\
15 Maret 2021 & psychological capital training has been held to enhance \\
& Resto X Salatiga employees' work engagement. the \\
\hline Keywords: & Paired T-Test score of 0,000 < $<$ shows that \\
Psychological & Capital, \\
Employee Work Attachment, & psychological capital training is successful in enhancing \\
Training & the employees'work engagement.
\end{tabular}

Kata Kunci:

Modal

Keterikatan

Pegawai, Pelatihan

\section{ABSTRAK}

Peningkatan kualitas tenaga kerja di masa pandemi COVID-19 dapat dikatakan sebagai suatu hal yang penting untuk dilakukan. Hal ini mengingat bahwa tenaga kerja yang unggul adalah suatu kebutuhan utama bagi para pengusaha di masa post-pandemic yang akan datang. Berdasarkan asesmen awal yang dilakukan, ditemukan bahwa pegawai Resto X Salatiga membutuhkan sebuah intervensi yang bersifat psikologis untuk meningkatkan keterikatan kerja mereka. Berdasarkan kebutuhan tersebut, maka disusunlah penelitian eksperimen lapangan ini, yakni berupa pemberian pelatihan modal psikologis yang bertujuan untuk meningkatkan keterikatan kerja pegawai resto $\mathrm{X}$ di Kota Salatiga. Hasil uji Paired T-Test pada sig.2-tailed menunjukkan skor Psikologis, $0,000<\alpha$, sehingga dapat dikatakan bahwa pelatihan Kerja modal psikologis cukup berhasil untuk meningkatkan keterikatan kerja pegawai resto X Salatiga.

\section{Coresponden Author}

Email: adi.wijaya@uksw.edu Artikel dengan akses terbuka dibawah lisensi 


\section{Pendahuluan}

Di Indonesia, usaha resto dan kafe yang menyajikan kopi dan minuman lainnya tengah menjadi tren di beberapa tahun belakangan ini. Hal ini tidak mengherankan, dikarenakan Indonesia sendiri merupakan salah satu negara penghasil kopi, dan eksportir kopi terbesar di dunia (Rosiana et al., 2018). Resto Kopi X sendiri merupakan sebuah resto yang menyajikan minuman olahan dari kopi dan beberapa menu makanan, dari makanan ringan hingga makanan yang cukup berat seperti cake dan pasta, serta hasil olahan daging ayam, ikan, dan sapi. Berdasarkan hasil wawancara bersama owner dan manager resto, diperoleh informasi bahwa mereka sama-sama ingin mengembangkan aspek psikologis pegawai mereka, sebagai bentuk dukungan perusahaan terhadap penguatan psikologis pegawai di masa pandemi COVID-19.

Pandemi COVID-19 memberikan dampak yang signifikan bagi berbagai lini usaha, termasuk salah satunya adalah usaha di bidang kuliner seperti restoran. Di Indonesia sendiri, dengan adanya usaha pengendalian penyebaran virus melalui kegiatan PSBB, banyak restoran yang mengalami penurunan pemasukan. Hal ini didukung oleh data dari (McKinsey et al., 2020) yang menunjukkan bahwa 60\% pelanggan Indonesia mengurangi pengeluaran diskresioner mereka, sebagai dampak dari berkurangnya pendapatan rumah tangga dan tabungan. Dengan situasi demikian, tidak menutup kemungkinan banyak usaha restoran memangkas pegawai yang dimilikinya guna bertahan di situasi tersebut. Jelas disini bahwa kinerja pegawai merupakan sumber daya yang paling dibutuhkan oleh sebuah usaha supaya dapat mencapai keberhasilan (Kappagoda et al., 2014).

Dalam konteks Resto Kopi X Salatiga sendiri, owner dan manager telah menyusun beberapa strategi guna menjaga resto tetap berjalan. Salah satu strategi yang dilakukan adalah dengan melakukan perubahan jam kerja dan penambahan layanan pesan-antar. Strategi ini tentunya dapat berhasil jika pegawai memiliki kinerja yang baik. Selain sistem dari perusahaan, kinerja pegawai juga ditentukan oleh sikap dari pegawai itu sendiri. Kinerja pegawai dapat dikatakan berkaitan dengan Work Engagement, yakni sebuah keadaan pikiran yang positif, mengisi, dan terkait dengan pekerjaan, yang ditandai dengan adanya semangat kerja/vigor, dedikasi/dedication, dan penyerapan/absorption (Bakker \& Demerouti, 2008) (Nerstad et al., 2010). Pegawai yang memiliki work engagement tinggi dikatakan memiliki beberapa karakteristik seperti memiliki energi dan keyakinan diri yang besar, yang dapat membantu mereka berlatih untuk mempengaruhi peristiwa-peristiwa yang terjadi dalam kehidupan mereka (Bakker \& Demerouti). Pandemi COVID-19 merupakan hal yang tidak terelakkan, dan menuntut baik perusahaan maupun individu untuk dapat beradaptasi dengan cara kerja baru, supaya tetap dapat bertahan. Dengan demikian, dapat dikatakan bahwa pengembangan work engagement di situasi pandemi ini diperlukan bagi pegawai Resto Kopi X Salatiga.

Kinerja pegawai dapat dikatakan berhubungan dengan faktor-faktor yang mempengaruhinya, dalam hal ini salah satunya adalah modal psikologis (Stremic et al., 2017). Modal psikologis dalam pengembangannya berakar dari perilaku positif dalam 
organisasi (Positive Organizational Behavior-POB), dijelaskan sebagai sebuah status psikis yang positif yang dimiliki individu yang dikarakteristikkan dengan adanya: 1) Efikasi diri dalam menghadapi tugas-tugas yang menantang, 2) Optimisme, 3) Pengharapan/Hope, dan 4) Resiliensi (Wirawan \& Tandiayuk, 2019).

Modal psikologis telah terbukti berhubungan dengan sikap kerja, kinerja dan keterikatan kerja pegawai itu sendiri (Bande et al., 2015) (Boot et al., 2013) (Karatepe \& Avci, 2017) (Gupta et al., 2017). Dalam penelitiannya mengenai pentingnya modal psikologis pada pegawai bidang pelayanan dan jasa (hospitality), (Paek et al., 2015) menemukan bahwa work engagement merupakan konsekuensi dari modal psikologis. Dalam penelitiannya ini, Paek et al menemukan hasil empiris dimana modal psikologis adalah prediktor yang kuat bagi tingkat work engagement pegawai, dan dalam hal ini menguatkan argumen bahwa pegawai pelayanan dan jasa yang menunjukkan tingkat modal psikologis yang tinggi cenderung akan menunjukkan tingkat work engagement yang tinggi pula (Paek et al). Selain itu, pada penelitian yang dilakukan oleh (Tsaur et al., 2019) menunjukkan bahwa modal psikologis memiliki peran menengah bagi Work Engagement pegawai. (Tsuji et al., 2019) lebih lanjut juga menjelaskan bahwa implementasi program modal psikologis dapat menghasilkan beberapa luaran positif seperti well-being, kinerja, subjective well-being, fungsi tim, engagement, kreativitas, inovasi, dan juga kepemimpinan. Dalam konteks Resto Kopi X Salatiga, pengembangan modal psikologis pegawai sendiri dengan bentuk intervensi apapun memang belum pernah dilakukan. Dengan mengacu beberapa penelitian terdahulu, peneliti kemudian tertarik untuk meneliti kembali, apakah modal psikologis juga turut dapat mempengaruhi Work Engagement, terutama pada pegawai Resto Kopi X tersebut.

Berdasarkan dari kebutuhan yang dikemukakan oleh perusahaan melalui owner dan manager Resto Kopi X Salatiga, maka peneliti hendak mengusulkan sebuah penelitian eksperimental dalam bentuk pelatihan, yakni pelatihan modal psikologis. Tujuan penelitian ini sendiri tentunya adalah untuk menjawab kebutuhan pegawai Resto Kopi X Salatiga, yakni terkait dengan pengembangan Work Engagement pegawainya. Adapun pertanyaan utama dalam penelitian ini adalah, "apakah ada pengaruh dari pemberian pelatihan modal psikologis terhadap keterikatan kerja pegawai Resto Kopi X Salatiga?". Hipotesis dalam penelitian ini adalah "pelatihan modal psikologis dapat meningkatkan keterikatan kerja pegawai Resto Kopi X Salatiga”.

\section{Metode Penelitian}

Penelitian ini merupakan penelitian eksperimen lapangan yang berusaha untuk menjawab kebutuhan dari sebuah unit usaha Resto Kopi X Salatiga. Penelitian ini melibatkan 21 orang pegawai Resto Kopi X Salatiga berusia 19-35 tahun. Desain penelitian yang digunakan adalah desain Kuasi Eksperimental, dan metode analisis menggunakan Uji Beda (Uji T) dengan menggunakan software olah data SPSS Ver. 22. Pelatihan diberi nama, "A True Hero in Difficult Times", dan diadakan selama enam (6) sesi pertemuan, yang mencakup materi, "Living Your Dream!", "Building Your Dreams through Shared Efficacy", "Hopeful Hero", "Be Resilient", "Understanding Yourself", 
dan, "Come On, We Do it!". Metode pelatihan yang digunakan dalam penelitian ini sendiri mencakup lecturing, Audio-Visual, Case Study, Paper Assignment, Diskusi, Roleplay dan Permainan indoor.

\section{Hasil dan Pembahasan}

Berdasarkan hasil asesmen kebutuhan pelatihan, ditemukan bahwa Resto Kopi X Salatiga membutuhkan sebuah pelatihan guna mengembangkan Work Engagement pegawainya. Berdasarkan proses penelitian yang telah dilaksanakan, diperoleh data sebagai berikut :

\section{Tabel 1}

Peserta Pelatihan

\begin{tabular}{cccc}
\hline No. & Nama (inisial) & Departemen & Keterangan \\
\hline 1. & D & Server & Hadir enam sesi \\
\hline 2. & J & Barista & Hadir enam sesi \\
\hline 3. & S & Barista & Hadir enam sesi \\
\hline 4. & H & Server & Hadir enam sesi \\
\hline 5. & F & Server & Hadir enam sesi \\
\hline 6. & R & Server & Hadir enam sesi \\
\hline 7. & Ra & Finance & Hadir enam sesi \\
\hline 8. & E & Purchasing & Hadir enam sesi \\
\hline 9. & Di & Cook & Hadir enam sesi \\
\hline 10. & Dm & Server & Hadir enam sesi \\
\hline 11. & En & Server & Hadir enam sesi \\
\hline 12. & B & Cook & Hadir enam sesi \\
\hline 13. & G & Server & Hadir enam sesi \\
\hline 14. & M & Server & Hadir enam sesi \\
\hline 15. & H & Cook & Hadir enam sesi \\
\hline 16. & Fr & Barista & Hadir enam sesi \\
\hline 17. & Az & Cook & Hadir enam sesi \\
\hline 18. & C & Server & Hadir enam sesi \\
\hline 19. & M & Cashier & Hadir enam sesi \\
\hline 20. & I & Barista & Hadir enam sesi \\
\hline 21. & T & Server & Hadir enam sesi \\
\hline
\end{tabular}

Sumber: Data Absensi Pelatihan "A True Hero in Difficult Times"

Tabel 2

Hasil Pelatihan Dari Segi Pengetahuan

\begin{tabular}{ccccccc}
\hline Hasil & \multicolumn{7}{c}{ Sesi } \\
\cline { 2 - 7 } & $\mathbf{1}$ & $\mathbf{2}$ & $\mathbf{3}$ & $\mathbf{4}$ & $\mathbf{5}$ & $\mathbf{6}$ \\
\hline Naik 1 Tingkat & 9 & 13 & 8 & 10 & 6 & 4 \\
\hline Naik 2 Tingkat & 7 & 3 & 3 & 6 & 11 & 10 \\
\hline Naik 3 Tingkat & - & - & - & - & 2 & - \\
\hline Tidak ada kenaikan tingkat & 5 & 5 & 10 & 5 & 2 & 7 \\
\hline Jumlah Peserta & 21 & 21 & 21 & 21 & 21 & 21 \\
\hline
\end{tabular}

Sumber: Data Pengukuran Level Pengetahuan Pelatihan "A True Hero in Difficult Times" 
Tabel 3

Hasil Pelatihan dari Segi Pengetahuan

\begin{tabular}{|c|c|c|c|c|}
\hline $\begin{array}{c}\text { Nilai Tinggi } \\
6\end{array}$ & $\begin{array}{l}\text { Nilai } \\
\text { Mean }\end{array}$ & $\begin{array}{c}\text { SD } \\
\text { Ideal }\end{array}$ & $\begin{array}{c}\text { Kategori } \\
\text { Norma }\end{array}$ & Skor \\
\hline & 51,00 & 17,00 & $\begin{array}{l}\text { Sangat } \\
\text { Rendah }\end{array}$ & $X<20,40$ \\
\hline Nilai Rendah & & & Rendah & $20,40 \leq X<40,80$ \\
\hline 0 & & & Cukup & $40,80 \leq X<61,20$ \\
\hline Total Butir & & & Tinggi & $61,20 \leq X<81,60$ \\
\hline 17 & & & $\begin{array}{l}\text { Sangat } \\
\text { Tinggi }\end{array}$ & $\mathrm{X} \geq 81,60$ \\
\hline
\end{tabular}

Sumber: Data Pengukuran Level Pengetahuan Pelatihan "A True Hero in Difficul Times"

Tabel 4

Skor Total dan Kategori Pretest-Posttest Work Engagement

\begin{tabular}{|c|c|c|c|c|c|c|c|}
\hline \multirow[t]{2}{*}{ No. } & \multirow{2}{*}{$\begin{array}{l}\text { Nama } \\
\text { Peserta }\end{array}$} & \multicolumn{4}{|c|}{$\begin{array}{c}\text { Skor Total dan Kategori Pretest-Posttest } \\
\text { Work Engagement }\end{array}$} & \multirow{2}{*}{$\begin{array}{l}\text { Selisih } \\
\text { Skor }\end{array}$} & \multirow[t]{2}{*}{ Keterangan } \\
\hline & & Pretest & Norma & Posttest & Norma & & \\
\hline 1 & $\mathrm{D}$ & 68 & Tinggi & 69 & Tinggi & 1 & $\begin{array}{c}\text { Tidak ada } \\
\text { peningkatan }\end{array}$ \\
\hline 2 & $\mathrm{~J}$ & 26 & Rendah & 68 & Tinggi & 42 & Naik 2 tingkat \\
\hline 3 & $\mathrm{~S}$ & 50 & Cukup & 65 & Tinggi & 15 & Naik 1 tingkat \\
\hline 4 & $\mathrm{H}$ & 51 & Cukup & 86 & Sangat Tinggi & 35 & Naik 2 tingkat \\
\hline 5 & $\mathrm{~F}$ & 35 & Rendah & 66 & Tinggi & 31 & Naik 2 tingkat \\
\hline 6 & $\mathrm{R}$ & 50 & Cukup & 90 & Sangat Tinggi & 40 & Naik 2 tingkat \\
\hline 7 & $\mathrm{Ra}$ & 47 & Cukup & 70 & Tinggi & 23 & Naik 1 tingkat \\
\hline 8 & $\mathrm{E}$ & 36 & Rendah & 78 & Tinggi & 42 & Naik 2 tingkat \\
\hline 9 & Di & 44 & Cukup & 85 & Sangat Tinggi & 41 & Naik 2 tingkat \\
\hline 10 & $\mathrm{Dm}$ & 21 & Rendah & 68 & Tinggi & 47 & Naik 2 tingkat \\
\hline 11 & En & 29 & Rendah & 56 & Cukup & 27 & Naik 1 tingkat \\
\hline 12 & $\mathrm{~B}$ & 57 & Cukup & 96 & Sangat Tinggi & 39 & Naik 2 tingkat \\
\hline 13 & G & 68 & Tinggi & 63 & Tinggi & -5 & $\begin{array}{l}\text { Tidak ada } \\
\text { peningkatan }\end{array}$ \\
\hline 14 & $\mathrm{M}$ & 28 & Rendah & 56 & Cukup & 28 & Naik 1 tingkat \\
\hline 15 & $\mathrm{H}$ & 42 & Cukup & 89 & Sangat Tinggi & 47 & Naik 2 tingkat \\
\hline 16 & Fr & 35 & Rendah & 63 & Tinggi & 28 & Naik 2 tingkat \\
\hline 17 & $\mathrm{Az}$ & 29 & Rendah & 70 & Tinggi & 41 & Naik 2 tingkat \\
\hline 18 & $\mathrm{C}$ & 23 & Rendah & 63 & Tinggi & 40 & Naik 2 tingkat \\
\hline 19 & M & 42 & Cukup & 59 & Cukup & 17 & $\begin{array}{c}\text { Tidak ada } \\
\text { peningkatan }\end{array}$ \\
\hline 20 & I & 21 & Rendah & 59 & Cukup & 38 & Naik 1 tingkat \\
\hline 21 & $\mathrm{~T}$ & 38 & Rendah & 80 & Tinggi & 42 & Naik 2 tingkat \\
\hline
\end{tabular}

Sumber: Data Pengukuran Pengukuran Level Sikap Pelatihan "A True Hero in Difficult Times" 
Efektivitas Pelatihan Modal Psikologis Terhadap Keterikatan Kerja Pegawai Resto Kopi X Salatiga

Tabel 5

Sebaran Peningkatan Pretest-Posttest Work Engagement

\begin{tabular}{lcc}
\hline \multicolumn{1}{c}{ Kategori } & $\begin{array}{c}\text { Jumlah } \\
\text { (orang) }\end{array}$ & Persentase \\
\hline Naik 1 tingkat & 5 & $24 \%$ \\
\hline Naik 2 tingkat & 13 & $62 \%$ \\
\hline Tidak ada peningkatan & 3 & $14 \%$ \\
\hline TOTAL & 21 & $100 \%$ \\
\hline
\end{tabular}

Sumber: Data Pengukuran Pengukuran Level Sikap Pelatihan "A True Hero in Difficult Times"

Tabel 6

Hasil Olah Data

\begin{tabular}{|c|c|c|c|c|c|c|c|c|c|}
\hline & & \multicolumn{5}{|c|}{ Paired Differences } & \multirow{3}{*}{$\begin{array}{c}\mathbf{t} \\
\text { Mean } \\
\text { Upper }\end{array}$} & \multirow{3}{*}{$\begin{array}{c}\text { df } \\
\begin{array}{c}\text { Std. } \\
\text { Deviat } \\
\text { ion }\end{array} \\
\text { Lower }\end{array}$} & \multirow{3}{*}{$\begin{array}{c}\text { Sig. } \\
(2- \\
\text { tailed })\end{array}$} \\
\hline & & \multirow{2}{*}{$\begin{array}{l}\text { Mean } \\
\text { Lower }\end{array}$} & \multirow{2}{*}{$\begin{array}{c}\begin{array}{c}\text { Std. } \\
\text { Deviation }\end{array} \\
\text { Upper }\end{array}$} & \multirow{2}{*}{$\begin{array}{l}\text { Std. } \\
\text { Error } \\
\text { Mean } \\
\text { Lower }\end{array}$} & \multicolumn{2}{|c|}{$\begin{array}{l}\text { 95\% Confidence } \\
\text { Interval of the } \\
\text { Difference }\end{array}$} & & & \\
\hline & & & & & Upper & Lower & & & \\
\hline $\begin{array}{l}\text { Pai } \\
\text { r } 1\end{array}$ & $\begin{array}{l}\text { PRE - } \\
\text { POST }\end{array}$ & $-31,381$ & 14,333 & 3,128 & $-37,905$ & $-24,856$ & $-10,033$ & 20 &, 000 \\
\hline
\end{tabular}

Sumber: Data Pengukuran Uji Beda Pelatihan "A True Hero in Difficult Times"

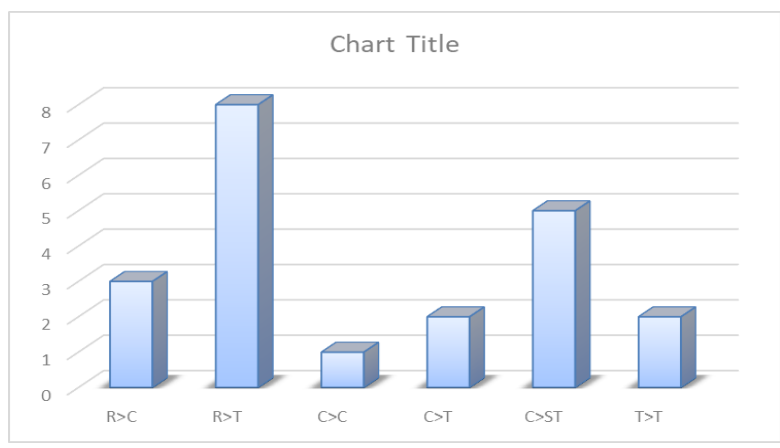

Grafik 1

Pengelompokan Perubahan Pretest-Posttest Work Engagement

Tabel 7

Analisis Statistik Hasil Pelatihan

Analisis

Nilai Signifikansi Keterangan

Knowledge : Living Your Dream! $\quad 0,000 \quad$ Signifikan

Knowledge : Building Your Dreams Through Shared Efficacy $\quad 0,000 \quad$ Signifikan

Knowledge : Hopeful Hero $\quad 0,000 \quad$ Signifikan

Knowledge : Be Resilient $\quad 0,000 \quad$ Signifikan

Knowledge : Understanding Yourself $\quad 0,000 \quad$ Signifikan

Knowledge : Come On, We Do it! $\quad 0,000 \quad$ Signifikan

Work Engagement $\quad 0,000 \quad$ Signifikan

Sumber: Data Pengukuran Uji Signifikansi Pelatihan "A True Hero in Difficult Times" 


\section{Tabel 8}

Hasil Pelatihan Work Engagement

\begin{tabular}{lc}
\hline \multicolumn{1}{c}{ Hasil } & Jumlah Peserta \\
\hline Naik 1 tingkat & 5 \\
\hline Naik 2 tingkat & 13 \\
\hline $\begin{array}{l}\text { Tidak ada kenaikan } \\
\text { tingkat }\end{array}$ & 3 \\
\hline
\end{tabular}

Sumber: Data Perubahan Sikap Pelatihan "A True Hero in Difficult Times"

Kondisi pandemi dapat dikatakan sebagai kondisi yang tidak menentu (Minton \& Cabano, 2020). Kondisi ini turut mengguncang perekonomian UMKM (Thaha, 2020). Guna membuat bisnis tetap berjalan, tentunya pengelolan UMKM harus turut mengembangkan Sumber Daya Manusia atau SDM-nya. Hal ini diperlukan, mengingat bahwa kondisi yang tak menentu akibat pandemi COVID-19 ini juga dapat membawa akibat bagi pegawai secara psikologis. Target usaha yang sulit dicapai karena daya beli masyarakat menurun, sementara kinerja tetap harus dipertahankan, membuat Work Engagement menjadi sesuatu yang harus dimiliki oleh pegawai.

Pelatihan yang diberi nama, "A True Hero in Difficult Times" ini berhasil oleh 21 orang pegawai Resto Kopi X Salatiga dan pada tabel 1 terlihat bahwa semua pegawai hadir di setiap sesi pelatihan. Pada tabel 2, ditunjukkan bahwa terjadi peningkatan pada pengukuran pengetahuan terkait modal psikologis, pada waktu sebelum dan sesudah diberikan pelatihan modal psikologis. Berdasarkan uji statistik dengan Paired T-Test didapatkan hasil pengolahan statistik yang ditampilkan dalam dua tabel. Pada tabel Test Statistic, dapat diketahui bahwa nilai Sig. (2-tailed) adalah $0,000<\alpha$. Hal ini menunjukkan bahwa terdapat perbedaan yang signifikan antara sebelum dan sesudah dilakukannya pemberian pelatihan terkait modal psikologis untuk meningkatkan Work Engagement pegawai Resto Kopi X Salatiga. Perubahan attitude peserta pelatihan saat pretest dan posttest cukup menunjukan kenaikannya. Peserta yang mengalami kenaikan dengan presentase sebesar $62 \%$ dengan kenaikan 2 tingkat. Peserta yang naik 1 tingkat sebanyak $24 \%$ dan terdapat $14 \%$ atau 3 orang yang tidak menunjukan kenaikan. Berdasarkan data tersebut, hal ini menandakan bahwa terdapat perubahan Work Engagement pegawai, dan pelatihan dapat dikatakan cukup berhasil untuk meningkatkan Work Engagement pegawai Resto Kopi X Salatiga.

Jika melihat pada penelitian-penelitian sebelumnya, telah dikemukakan bahwa Work Engagement tidak akan muncul tanpa adanya modal psikologis (Karatepe \& Avci, 2017) (Gupta et al., 2017). Hasil penelitian ini turut mendukung temuan penelitian sebelumnya, yakni bahwa modal psikologis adalah salah satu yang menjadi anteseden bagi munculnya Work Engagement (Alkahtani et al., 2020), dan bahwa pegawai yang engaged adalah pegawai yang cenderung memiliki modal psikologis yang tinggi (Joo et al., 2016). Berdasarkan hasil wawancara follow up bersama para pegawai Resto Kopi X Salatiga, meningkatnya tingkat Work Engagement pada pegawai Resto Kopi X Salatiga adalah dikarenakan bahwa setelah diberikan pelatihan terkait dengan pengembangan kemampuan modal psikologis, mereka dapat berpikir lebih positif terhadap situasi 
ketidakpastian yang dikarenakan pandemic COVID-19 ini, dibandingkan berfokus pada kecemasan akan dirumahkan jika Resto terpaksa berhenti sementara waktu. Hal ini sejalan dengan temuan penelitian Manzano-Gracia \& Ayala (2017), bahwa ketika seorang individu mampu memanfaatkan modal psikologis, maka ia cenderung dapat meningkatkan kesejahteraan psikologisnya; dalam hal ini, kemungkinan dampak negatif dari stress dapat dihindarkan, dan kemampuan membangun strategi coping dalam bekerja menjadi lebih baik.

\section{Kesimpulan}

Pelatihan ini menjawab hipotesis awal yang diajukan oleh peneliti, yakni bahwa pelatihan modal psikologis dapat meningkatkan keterikatan kerja/Work Engagement pegawai Resto Kopi X Salatiga. Secara keseluruhan, pegawai Resto X Salatiga mengalami peningkatan baik dari sisi pengetahuan maupun sikap yakni keterikatan kerja/Work Engagement-nya. Hal ini tentunya memperkuat hasil penelitian-penelitian sebelumnya yang menyatakan bahwa modal psikologis turut mempengaruhi pengembangan Work Engagement pada pegawai. Penelitian lebih lanjut di area ini dapat melakukan pengembangan terkait hubungan pelatihan softskills (modal psikologis) dan hardskills yang dimiliki pegawai seperti strategi penjualan, product knowledge dengan keterikatan kerja. Selain itu, dapat dikaji lebih lanjut terkait dengan pembuatan sistem pengembangan sumber daya manusia ketika menghadapi situasi yang tidak pasti/sulit bagi unit usaha kecil. 


\section{BIBLIOGRAFI}

Alkahtani, N. S., MM, S., Delany, K., \& Adow, A. H. E. (2020). Psycap And Workplace Social Capital As Antecedents Of Employee Engagement: A Study Among Saudi Arabian Workforce. Talent Development \& Excellence, 12(2).

Bakker, A. B., \& Demerouti, E. (2008). Towards A Model Of Work Engagement. Career Development International.

Bande, B., Fernández-Ferrín, P., Varela, J. A., \& Jaramillo, F. (2015). Emotions And Salesperson Propensity To Leave: The Effects Of Emotional Intelligence And Resilience. Industrial Marketing Management, 44, 142-153.

Boot, W. R., Simons, D. J., Stothart, C., \& Stutts, C. (2013). The Pervasive Problem With Placebos In Psychology: Why Active Control Groups Are Not Sufficient To Rule Out Placebo Effects. Perspectives On Psychological Science, 8(4), 445-454.

Gupta, M., Shaheen, M., \& Reddy, P. K. (2017). Impact Of Psychological Capital On Organizational Citizenship Behavior: Mediation By Work Engagement. Journal Of Management Development.

Joo, B.-K., Lim, D. H., \& Kim, S. (2016). Enhancing Work Engagement. Leadership \& Organization Development Journal.

Kappagoda, U. S., Othman, H. Z. F., \& De Alwis, G. (2014). Psychological Capital And Job Performance: The Mediating Role Of Work Attitudes. Journal Of Human Resource And Sustainability Studies, 2(02), 102.

Karatepe, O. M., \& Avci, T. (2017). The Effects Of Psychological Capital And Work Engagement On Nurses' Lateness Attitude And Turnover Intentions. Journal of Management Development.

Mckinsey, G. L., Lizama, C. O., Keown-Lang, A. E., Niu, A., Santander, N., Larpthaveesarp, A., Chee, E., Gonzalez, F. F., \& Arnold, T. D. (2020). A New Genetic Strategy For Targeting Microglia In Development And Disease. Elife, 9, E54590.

Minton, E. A., \& Cabano, F. G. (2020). Religiosity's Influence On Stability-Seeking Consumption During Times Of Great Uncertainty: The Case Of The Coronavirus Pandemic. Marketing Letters, 1-14.

Nerstad, C. G. L., Richardsen, A. M., \& Martinussen, M. (2010). Factorial Validity Of The Utrecht Work Engagement Scale (UWES) Across Occupational Groups In Norway. Scandinavian Journal Of Psychology, 51(4), 326-333.

Paek, S., Schuckert, M., Kim, T. T., \& Lee, G. (2015). Why Is Hospitality Employees' Psychological Capital Important? The Effects Of Psychological Capital On Work Engagement And Employee Morale. International Journal Of Hospitality Management, 50, 9-26. 
Efektivitas Pelatihan Modal Psikologis Terhadap Keterikatan Kerja Pegawai Resto Kopi $\mathrm{X}$ Salatiga

Rosiana, N., Nurmalina, R., Winandi, R., \& Rifin, A. (2018). Dynamics Of Indonesian Robusta Coffee Competition Among Major Competitor Countries.

Stremic, S. M., Mussleman, M. E., Thiele, A., Jackson, A. T., \& Frame, M. C. (2017). Employee Characteristics: Resilience And Self-Efficacy As Protective Factors.

Thaha, A. F. (2020). Dampak Covid-19 Terhadap UMKM Di Indonesia. BRAND Jurnal Ilmiah Manajemen Pemasaran, 2(1), 147-153.

Tsaur, S.-H., Hsu, F.-S., \& Lin, H. (2019). Workplace Fun And Work Engagement In Tourism And Hospitality: The Role Of Psychological Capital. International Journal Of Hospitality Management, 81, 131-140.

Tsuji, S., Sato, N., Yano, K., Broad, J., \& Luthans, F. (2019). Employees' Wearable Measure Of Face-To-Face Communication Relates To Their Positive Psychological Capital, Well-Being. IEEE/WIC/ACM International Conference On Web Intelligence-Companion Volume, 14-20.

Wirawan, H., \& Tandiayuk, S. (2019). The Role Of Charisma And Psychological Capital On Credibility Among Start-Up Entrepreneurs. Jurnal Ilmiah Ilmu Administrasi Publik, 8(2), 107-120. 